\title{
Kesesuaian Lahan Tanaman Kedelai Berdasarkan Masukan Teknologi dan Produktivitas Lahan di Kecamatan Dawan
}

\author{
Kadek Ary Kumala Dewi ${ }^{1 *}$, I Putu Sriartha ${ }^{2}$, Ida Bagus Made Astawa ${ }^{3}$
}

1 Jurusan Geografi, Universitas Pendidikan Ganesha, Singaraja, Indonesia

${ }^{2} J u r u s a n$ Geografi, Universitas Pendidikan Ganesha, Singaraja, Indonesia

3 Jurusan Geografi, Universitas Pendidikan Ganesha, Singaraja , Indonesia

\section{A R T I C L E I N F O}

Article history:

Received 28 July 2020

Received in revised form 20 August 2020

Accepted 30 August 2020

Available online 31 August 2020

\section{Kata Kunci:}

Kesesuaian Lahan

Masukan

Teknologi,Produktivitas

Lahan.

Keywords:

The Land Suitability, The

Input Of Technilogy, Land

Productivity.

\begin{abstract}
A B S T R A K
Penelitian ini bertujuan untuk menganalisis kesesuaian lahan tanaman kedelai berdasarkan masukan teknologi dan produktivitas lahan, dan kendala-kendala petani kedelai dalam menentukan masukan teknologi dan produktivitas lahan. Populasi dalam penelitian ini adalah 5 unit lahan yang ditanami kedelai dan sampel petani kedelai dalam penelitian ini berjumlah 30 orang. Metode pengumpulan data yang digunakan adalah metode observasi, wawancara, dan pencatatan dokumen. Analisis data yang digunakan yaitu analisis deskriptif kualitatif. Hasil penelitian menunjukkan bahwa rata-rata ketepatan masukan teknologi mencapai tahap pelaksanaan $48,36 \%$ termasuk dalam katagori sedang. Unit lahan 16 menunjukkan nilai rata-rata ketepatan masukan teknologi tertinggi mencapai tahap pelaksanaan sebesar $56,89 \%$ termasuk dalam katagori sedang, sedangkan unit lahan 10 menunjukkan rata-rata ketepatan masukan teknologi terendah mencapai tahap pelaksanaan sebesar $40,34 \%$ termasuk dalam katagori kurang baik. Rata-rata produktivitas
\end{abstract} lahan untuk tanaman kedelai sebesar Rp. 4.993.102,99/ha. Produktivitas lahan tertinggi ditunjukkan oleh unit lahan 13 sebeaar Rp. 8.548.578,86/ha, sedangkan produktivitas terendah terdapat pada unit lahan 10 sebesar Rp. 3.181.308,41/ha. Kendala-kendala yang dihadapi petani selama menanam kedelai yaitu, kesulitan bibit unggul, serangan hama, cuaca buruk, dan harga panen kedelai yang rendah.

\section{A B S T R A C T}

This research aiming to analyze the land suitability of soybean farm in accordance with the input of tecnology and the land productivity, and the challenges and the obstacles faced by the farmers when determining the input of technology and the land productivity. The population of this study is limited to 5 units soybean farms and the sampel is 30 farmers. The method used for collecting the data are by observations, interviews and documentation. The analysis of the these three aspects uses qualitative descriptive analysis method. The result if this research shows that the average value in percentage of the input of technology accuracy is $48,36 \%$, this percentage is classified into moderate category. The land unit of number 16 shows the gighest average value of the input of technology accurary which is at $56,89 \%$ and classified into moderate category. While, the land unit number 10 shows the lowest average value at $40,34 \%$ and classified as low category. The average productivity amount for this soybean land is calculated at IDR 4.993.102,99 per hectare. The gidhest average productivity is shown by the land unit of number 13 at IDR $8.548 .578,86$ per hectare, while the lowest one is shown by the land unit of number 10 at IDR $3.181 .308,41$ per hectare. The obstacles faced by the farmers during the planting season are the difficulty to find best seeds, pests attacks, bad weather, and low harvest proces.

\footnotetext{
* Corresponding author.

E-mail addresses: arykumaladewi5@gmail.com
} 


\section{Pendahuluan}

Geografi Pertanian merupakan salah satu cabang ilmu geografi yang mempelajari persamaan dan perbedaan fenomena pertanian di permukaan bumi yang dikaji dengan pendekatan ekologi, dan regional dalam konteks keruangan (Sriartha, 2000). Sebagai negara agraris sektor pertanian memiliki peranan penting dalam struktur pembangunan perekonomian nasional. Pembangunan sektor pertanian harus menjadi prioritas pembangunan guna menuju keberhasilan industralisasi. Berkenaan dengan itu penting mengetahui informasi terkait kesesuaian lahan sebagai modal dasar informasi untuk dapat mengolah lahan pertanian secara efektif, efisien dan berkesinambungan. Penilaian yang dilakukan tidak hanya sebatas pada penilaian karakteristik/kualitas lahan saja melainkan kosekuensi sosial dan dampak lingkungan yang timbul juga wajib mendapat perhatian (Mega, Dibia, Ratna, Adi dan Tati, 2010).

Kesesuaian lahan lazim diklasifikasikan menjadi beberapa cara, yakni cara kualitatif dan cara kuantitatif. Kesesuaian lahan kualitatif menekankan pada penelitian sifat fisik lahan tanpa memperhitungkan secara tepat produksi, masukan dan keuntungan yang diperoleh. Kesesualaian kuantitatif merupakan penelitian kesesuaian lahan secara fisik yang dilanjutkan pada aspek ekonomi seperti input-output atau cost benefit (FAO,1976). Sejauh ini evaluasi lahan secara kuantitatif belum banyak dilakukan, walaupun sejatinya cara ini sangat penting untuk memberikan deskripsi keuntungan dan kerugian dari produk pertanian yang diusahakan pada suatu areal tertentu. Semakin tidak sesuai suatu lahan untuk tanaman tertentu, maka akan membutuhkan pembiayaan yang lebih tinggi dalam pemeliharaannya dan pengelolaannya, selain produk yang dihasilkan tidak akan maksimal.

Kecamatan Dawan merupakan salah satu kecamatan yang ada di Kabupaten Klungkung dengan luas wilayah mencapai $37,38 \mathrm{~km}^{2}$ atau sekitar $11,87 \%$ dari luas wilayah Kabupaten Klungkung (BPS Kab. Klungkung, 2018). Pertanian yang diusahakan di Kecamatan Dawan sangat beragam yakni terdiri dari pertanian lahan kering dan pertanian lahan basah. Pertanian lahan basah umumnya ditanami tanaman pangan dan tanaman palawija. Tanaman kedelai merupakan salah satu tanaman dominan yang diusahakan dan menjadi ciri khas produk pertanian di Kecamatan Dawan.

Maitri (2011) dalam penelitiannya terkait pengaruh kesesuaian lahan terhadap produktivitas lahan kering untuk tanaman kedelai di Kecamatan Dawan memberikan kontribusi bahwa kemampuan lahan untuk suatu tanaman tertentu sebagai dasar menentukan kesesuaian lahan sangatlah penting. Penelitian kesesuaian lahan kualitatif yang telah dilakukan di Kecamatan Dawan untuk tanaman kedelai menghasilkan persebaran kelas kesesuaian lahan cukup sesuai $\left(\mathrm{S}_{2}\right) 10 \%$, hampir sesuai $\left(\mathrm{S}_{3}\right) 40 \%$, tidak sesuai saat ini $\left(\mathrm{N}_{1}\right)$ $30 \%$, dan tidak sesuai selamanya $\left(\mathrm{N}_{2}\right) 20 \%$. Adapun persebaran kesesualan ahan untuk tanaman kedelai di Kecamatan Dawan dapat diperhatikan pada Tabel 1.

Tabel 1. Kesesuaian Lahan Kualitatif untuk Tanaman Kedelai di Kecamatan Dawan

\begin{tabular}{|c|c|c|c|c|c|}
\hline \multirow[t]{2}{*}{ No } & \multirow{2}{*}{$\begin{array}{l}\text { Satuan } \\
\text { Pemetaan }\end{array}$} & \multicolumn{2}{|c|}{ Kesesuaian Lahan } & \multicolumn{2}{|c|}{ Luas } \\
\hline & & Kelas & $\begin{array}{l}\text { Sub } \\
\text { Kelas }\end{array}$ & $\mathrm{Ha}$ & $\begin{array}{l}\text { Presentase } \\
(\%)\end{array}$ \\
\hline (1) & (2) & (3) & (4) & (5) & (6) \\
\hline 1 & 1 & $\mathrm{~S}_{2}$ & $S_{2 \text { trf }}$ & 20,00 & 1,13 \\
\hline 2 & 7 & $\mathrm{~N}_{1}$ & $\mathrm{~N}_{1 \mathrm{~s}}$ & 33,00 & 1,87 \\
\hline 3 & 10 & $\mathrm{~S}_{3}$ & $S_{3 r s}$ & 132,22 & 7,51 \\
\hline 4 & 13 & $\mathrm{~S}_{3}$ & $S_{3 n s}$ & 486,91 & 27,66 \\
\hline 5 & 15 & $\mathrm{~S}_{3}$ & $S_{3 s}$ & 26,86 & 1,52 \\
\hline 6 & 16 & $\mathrm{~S}_{3}$ & $S_{3 s}$ & 116,43 & 6,64 \\
\hline 7 & 18 & $\mathrm{~N}_{1}$ & $\mathrm{~N}_{1 \mathrm{~s}}$ & 106,43 & 6,05 \\
\hline 8 & 21 & $\mathrm{~N}_{1}$ & $\mathrm{~N}_{1 \mathrm{~s}}$ & 499,56 & 28,37 \\
\hline 9 & 24 & $\mathrm{~N}_{2}$ & $\mathrm{~N}_{2 \mathrm{~s}}$ & 196,76 & 11,18 \\
\hline 10 & 26 & $\mathrm{~N}_{2}$ & $\mathrm{~N}_{2 \mathrm{~s}}$ & 142,16 & 8,07 \\
\hline \multicolumn{4}{|c|}{ Jumlah } & 1760,65 & 100 \\
\hline
\end{tabular}

Sumber : Maitri (2011). Keterangan: $S_{1}=$ sangat sesuai; $S_{2}=$ cukup sesuai; $S_{3}=$ hampir sesuai; $N_{1}=$ tidak sesuai saat ini; $N_{2}=$ tidak sesuai selamanya; $t=$ temperatur; $w=$ ketersediaan air; $r=$ kondisi perakaran; $f=$ daya menahan unsur hara; $n=$ ketersediaan unsur hara; $x=$ keracunan; $s=$ medan.

Berdasarkan tabel tersebut dapat diketahui persebaran kelas kesesuaian lahan dan faktor pembatas setiap unit lahan yang ada. Mengetahui informasi kesesuaian lahan secara kualitatif maka dapat dilanjutkan untuk mengidentifikasi terkait kesesuaian lahan secara kuantitatif mengenai berbagai masukan teknologi 
yang dilakukan untuk meningkatkan kualitas lahan pada unit lahan. Penelitian sebelumnya terkait evaluasi lahan untuk tanaman kedelai di Kecamatan Dawan belum mengungkapkan permasalahan terkait kesesuaian lahan yang ditinjau dari masukan teknologi dan produktivitas lahannya. Informasi yang diperoleh hanya sebatas mengenai kualitas lahan yang membatasi tumbuhnya tanaman kedelai. belum ditemukannya gambaran terkait keuntungan ataupun kerugian yang diusahakan oleh petani untuk tanaman kedelai dan usaha yang dilakukan petani untuk lahannya agar tetap konsisten untuk tanaman kedelai.

Kecamatan Dawan yang sebagaian besar areal lahan pertanian yang ditanami kedelai memiliki pertumbuhan yang tidak maksimal. Terdapat perbedaan produktivitas lahan di masing-masing unit lahannya sehingga menimbulkan kerugian di beberapa unit lahan. Kesesuaian lahan kuantitatif dapat memberikan informasi dan gambaran terkait faktor pembatas yang mempengaruhi kualitas lahan pada setiap unit lahan. Faktor pembatas selanjutnya dijadikan syarat menentukan ketepatan masukan teknologi pada setiap unit lahan. Ketepatan masukan teknologi pada setiap unit lahan dapat memungkinkan peningkatan produktivitas lahan untuk tanaman kedelai di Kecamatan Dawan. Hal ini dapat mengungkapkan dan mengatasi permasalahan terhadap kualitas lahan. Diketahui pula produktivitas lahan untuk tanaman kedelai serta kendala-kendala yang dihadapi petani kedelai dalam menentukan ketepatan masukan teknologi dan meningkatkan produktivitas lahan.

Mengungkap permasalahan terkait kesesuaian lahan untuk tanaman kedelai di Kecamatan Dawan, akan dikaji menggunakan pendekatan ekologi dengan analisis interaksi antara kegiatan manusia dengan lingkungannya. Pendekatan ini menekankan pada jenis kegiatan manusia di permukaan bumi sangat banyak dan keberadaan mereka sangat di pengaruhi oleh faktor-faktor lingkungan yang ada (Yunus, 2010).

Melalui analisis ekologi ini diharapkan dapat menemukan ketepatan masukan teknologi terhadap faktor pembatas kesesuaian lahan pada tingkat sub kelas dan produktivitas lahan untuk tanaman kedelai. Penekanan pada interaksi kegiatan petani dalam melakukan pengolahan terhadap lingkungan tumbuhnya kedelai serta kendala-kendala yang dihadapi oleh petani terkait menentukan masukan teknologi dan meningkatkan produktivitas lahannya. Cakupan dalam penelitian ini yaitu geografi pertanian dengan objek ketepatan masukan teknologi untuk tanaman kedelai, produktivitas lahan dan kendala yang dihadapi petani dalam menentukan ketepatan masukan teknologi dan meningkatkan produktivitas lahan. Subjek penelitian yang dikaji hanya pada petani kedelai yang ada di Kecamatan Dawan.

Penelitian mengenai kesesuaian lahan berdasarkan kualitas lahannya telah banyak dilakukan, namun penelitian secara kuantitatif belum banyak dilakukan. Seperti penelitian yang telah dilakukan Maitri (2011) yang telah dijelaskan sebelumnya menghasilkan persebaran kesesuaian lahan berdasarkan kualitas lahannya. Selain itu, Adnyana (2012) telah melakukan penelitian kesesuaian lahan secara kuantitatif terhadap tanaman mangga di Kecamatan Tejakula terkait masukan teknologi dan produktivitas lahan. Penelitian ini sangat penting untuk dilakukan melihat penelitian sebelumnya yang dilakukan untuk tanaman mangga dapat memberikan gambaran terkait ketepatan masukan teknologi yang dilakukan petani untuk lahan dan produktivitas lahannya.

Selistiyono (2010) juga telah melakukan penelitian evaluasi kesesuaian lahan dan produktivitas tanaman jagung di DAS Grindulu Hulu Kabupaten Pacitan dan Kabupaten Ponorogo yang mana hasil dari penelitian ini memberikan gambaran terkait tingkat sub kelas kesesuaian lahan untuk tanaman jagung dan produktivitas tanaman jagung pada lahan jagung di setiap sub kelas kesesuaian lahan yang ada. Berdasarkan penelitian yang dilakukan oleh Faizin (2017) tentang evaluasi kesesuaian lahan tanaman padi, jagung, dan jeruk pada tanah sawah di Kecamatan Kencong, Jombang dan Umbulsari Kabupaten Jember, yang mana hasil dari penelitian ini menyediakan informasi terkait kelas kesesuaian lahan tanaman padi, jagung dan jeruk dengan faktor pembatasnya di Kecamatan Kencong, Jombang, dan Umbulsari Kabupaten Jember.

Penelitian yang akan dilakukan menekankan pada evaluasi kesesuaian lahan secara kuantitatif terkait ketepatan masukan teknologi, produktivitas lahan dan kendala yang dihadapi petani. Hal ini penting dilakukan kerena belum diketahuinya ketepatan masukan teknologi, produktivitas lahan dan kendala petani kedelai di Kecamatan Dawan. Karena secara umum evaluasi kesesuaian lahan dapat dilakukan dengan 2 cara yaitu secara kualitatif (fisik lahan), dan secara kuantitatif (mempertimbangkan aspek ekonomi, sosial dan lingkungan) (Arsyd,1989, dalam Sektiawan, 2005). Kesesuaian lahan kuantitatif dilkukan setelah dilaksanakannya evaluasi lahan secara kualitatif pada suatu unit lahan. Hasil evaluasi lahan secara kuantitatif akan memberikan informasi keuntungan dan resiko kerugian dari suatu komoditas yang diusahakan pada tingkat manajemen tertentu (Rossiter, 1994, dalam Djaenudin,2008). 


\section{Metode}

Rancangan penelitian ini menggunakan penelitian deskriptif yang menguraikan keadaan dilapangan mengenai kesesuaian lahan secara kuantitatif untuk tanaman kedelai di Kecamatan Dawan. Rancangan penelitian ini terdiri dari beberapa tahapan yaitu tahap perencanaan atau persiapan, tahap pelaksanaan dan tahap penyusunan laporan atau tahap akhir. Penelitian ini berlokasi di Kecamatan Dawan karena wilayah ini merupakan penghasil kedelai terbanyak di Kabupaten Klungkung.

Objek penelitian ini yaitu kesesuaian lahan kuantitatif berdasarkan ketepatan masukan teknologi terhadap faktor pembatas lahan, produktivitas lahan dan kendala petani kedelai. Sementara untuk subjek penelitian ini adalah unit lahan dan petani kedelai yang selanjutnya dijadikan populasi. Penelitian ini menggunakan penelitian populasi untuk unit lahan yaitu 5 unit lahan dan populasi petani kedelai berjumlah 297 orang di 5 unit lahan tersebut. Sedangkan untuk sampel petani kedelai sejumlah 30 orang di seluruh unit lahan yang ditanami kedelai yang diambil secara acak atau menggunakan Proportional Random Sampling sebesar $10 \%$.

Jenis data yang digunakan dalam penelitian ini adalah data primer (Masukan Teknologi, Produktivitas Lahan dan Kendala Petani) dan data sekunder (Keadaan Penduduk, Kondisi fisik wilayah, dan peta). Data primer diperoleh atau dikumpulkan melalui observasi, kuisioner dan wawancara dan data sekunder diperoleh melalui pencatatan dokumen yang diperoleh dari instansi terkait. Metode dan teknik analisis data yang digunakan dalam penelitian ini yaitu untuk ketepatan masukan teknologi diolah dengan menentukan skor tertinggi dan terendah setiap aspek dari faktor pembatas yang mana skor tertinggi diperoleh melalui nilai tertinggi dikali jumlah pertanyaan dan begitu sebaliknya untuk skor terendah. Katagori pelaksanaan usaha petani untuk memberikan masukan teknologi (Maitri, 2011) sebagai berikut:

1. Katagori tidak baik dengan presentase $0-20 \%$,

2. Katagori kurang baik dengan presentase $21-40 \%$,

3. Katagori sedang dengan presentase $41-60 \%$,

4. Katagori baik dengan presentase $61-80 \%$,

5. Katagori sangat baik dengan presentase $81-100 \%$. (Adnyana,2012).

Untuk pengolahan produktivitas lahan dihitung menggunakan rumus produktivitas sebagai berikut : $\frac{\text { Pendapatan }- \text { Biaya }}{h a}(1$ kali produksi $)=$ produktivitas

Setelah perhitungan selesai, akan dilakukan pengkatagorian sesuai dengan nilai yang diperoleh. Analisis yang digunakan untuk masukan teknologi dan produktivitas lahan menggunakan analisis deskriptif kualitatif dengan bantuan tabel untuk melihat secara kualitatif perbandingan kesesuaian lahan yang mencakup masukan dan produktivitas lahan antar kelas yang satu dengan yang lainnya.

Kendala-kendala petani kedelai diolah dengan mengklasifikasikan kendala petani sesuai dengan aspek yang ada lalu ditentukan kendala yang mendominasi permasalahan petani kedelai dalam mengolah lahan kedelainya. Analisis data yang digunakan yaitu analisis deskriptif kualitatif yang dilakukan dengan cara mendeskripsikan secara kuantitatif yang nantinya dapat ditarik kesimpulan.

\section{Hasil dan pembahasan}

\section{Kesesuaian Lahan Tanaman Kedelai Berdasarkan Masukan Teknologi dan Produktivitas Lahan}

Data ketepatan masukan teknologi terhadap pembatas kesesuaian lahan pada tingkat sub kelas di masing-masing unit lahan untuk tanaman kedelai dan produktivitas lahan tanaman kedelai diperoleh melalui hasil kuisioner dan wawancara dengan 30 Petani Kedelai sebagai sampel penelitian di daerah penelitian. Hasil penelitian terkait ketepatan masukan teknologi dan produktivitas lahan untuk tanaman kedelai di Kecamatan Dawan dapat dilihat pada penjelasan berikut.

\section{Ketepatan Masukan Teknologi Terhadap Pembatas Kesesuaian Lahan pada Tingkat Sub Kelas di Masing-Masing Unit Lahan Untuk Tanaman Kedelai di Kecamatan Dawan}

Faktor pembatas kesesuaian lahan yang ada di daerah penelitian tersebar di 5 unit lahan yang masih membudidayakan tanaman kedelai. Menurut Maitri (2011), unit lahan 1 memiliki faktor pembatas kualitas lahan temperatur $(\mathrm{t})$, media perakaran ( $\mathrm{r}$ ), dan retensi hara (f), unit lahan 7 memiliki faktor pembatas kualitas lahan meliputi medan (s). Unit lahan 10 memiliki faktor pembatas kualitas lahan meliputi media perakaran (r), dan medan (s), faktor pembatas pada unit 13 terdiri dari ketersediaan unsur hara (n), dan medan (s) serta unit 16 memiliki faktor pembatas lahan berupa medan (s). Berikut adalah rata-rata hasil dari ketepatan masukan teknologi terhadap pembatas lahan. 
Tabel 2. Rata-Rata Nilai Setiap Aspek dan Ketepatan Masukan Teknologi Terhadap Faktor Pembatas Kesesuaian Lahan untuk Tanaman Kedelai pada Tingkat Sub Kelas di Setiap Unit Lahan

\begin{tabular}{|c|c|c|c|c|c|c|c|c|c|c|c|}
\hline \multirow{2}{*}{ No } & \multirow{2}{*}{ SP } & \multicolumn{2}{|c|}{$\begin{array}{c}\text { Kesesuaian } \\
\text { Lahan }\end{array}$} & \multicolumn{5}{|c|}{ Rata-Rata Jumlah Nilai Tiap Aspek } & \multirow{2}{*}{$\begin{array}{c}\text { Rata-Rata } \\
\text { Jumlah Nilai } \\
\text { Semua } \\
\text { Aspek }\end{array}$} & \multirow{2}{*}{$\begin{array}{l}\text { Ketepatan } \\
\text { Masukan } \\
\text { Teknologi }\end{array}$} & \multirow{2}{*}{$\begin{array}{c}\text { Presentase } \\
\text { (\%) }\end{array}$} \\
\hline & & Kelas & $\begin{array}{l}\text { Sub } \\
\text { Kelas }\end{array}$ & $r$ & $\mathbf{n}$ & $\mathbf{T}$ & $f$ & $s$ & & & \\
\hline [1] & [2] & [3] & [4] & [5] & [6] & [7] & [8] & [9] & [10] & [11] & [12] \\
\hline 1 & 1 & $\mathrm{~S}_{2}$ & $S_{2 \text { trrf }}$ & 25,5 & 39 & 9 & 26 & 14 & 113,5 & 48,2978723 & 48,2979 \\
\hline 2 & 7 & $\mathrm{~N}_{1}$ & $\mathrm{~N}_{1 \mathrm{~s}}$ & 30,5 & 35,83 & 5,5 & 21,67 & 12 & 105,5 & 44,893617 & 44,8936 \\
\hline 3 & 10 & $\mathrm{~S}_{3}$ & $\mathrm{~S}_{3 \mathrm{rs}}$ & 33,6 & 24,6 & 3,8 & 20,4 & 12,4 & 94,8 & 40,3404255 & 40,3404 \\
\hline 4 & 13 & $\mathrm{~S}_{3}$ & $S_{3 n s}$ & 43,67 & 33,2 & 7,2 & 21,2 & 15,67 & 120,94 & 51,4638298 & 51,4638 \\
\hline 5 & 16 & $S_{3}$ & $\mathrm{~S}_{3 \mathrm{~s}}$ & 48,875 & 37,75 & 6,5 & 22,5 & 17,88 & 133,5 & 56,8085106 & 56,8085 \\
\hline \multicolumn{4}{|c|}{ Jumlah } & 182,15 & 170,38 & 32 & 111,77 & 71,95 & 568,24 & 241,804255 & 241,804 \\
\hline \multicolumn{4}{|c|}{ Rata-Rata } & 36,429 & 34,076 & 6,4 & 22,354 & 14,39 & 113,648 & 48,3608511 & 48,3609 \\
\hline \multicolumn{4}{|c|}{ Presentase (\%) } & 66,235 & 45,435 & 42,667 & 49,676 & 31,98 & $\begin{array}{c}48,3608510 \\
6\end{array}$ & 48,361 & 48,361 \\
\hline
\end{tabular}

Keterangan :

- $\quad$ SP : Satuan Pemetaan; $S_{2}$ : cukup sesuai, $S_{3}$ : Hampir Sesuai, $N_{1}$ : Tidak sesuai saat ini, $r$ : Media

Perakaran, $\mathrm{n}$ : Ketersediaan unsur hara, t : Temperatur/suhu, f : Retensi Hara, s : Medan

- $\quad \operatorname{Kolom}(11)=\frac{\text { Kolom (10) }}{\text { Skor Maksimal Tiap Unit Lahan }} \times 100$

Berdasarkan Tabel 2. tersebut, rata-rata nilai ketepatan masukan teknologi terhadap faktor pembatas kesesuaian lahan pada tingkat sub kelas adalah 48,36 yang mencapai tahap pelaksanaan 48,36\% yang termasuk kedalam katagori sedang. Hal ini menunjukkan bahwa ketepatan masukan teknologi untuk mengatasi faktor pembatas kesesuaian lahan masih kurang maksimal sehingga diperlukan usaha yang lebih baik agar pelaksanaannya jauh lebih baik. Memperhatikan setiap aspek yang ada, terlihat aspek yang paling tinggi tahap pelaksanaannya adalah aspek media perakaran dengan rata-rata nilai 36,43 yang mencapai tahap pelaksanaan $66,24 \%$ termasuk kedalam katagori baik. Kondisi pemeliharaan ini akan mengurangi tingkat kegagalan panen dalam suatu produksi tanaman kedelai. Selain itu, terlihat pula aspek yang paling rendah tahap pelaksanaannya yaitu medan dengan rata-rata nilai mencapai 14,39 dengan capaian tahap pelaksanaan sebesar 31,98\%. Kondisi ini sejalan dengan medan yang ada tidak terlalu terjal dan kemiringan setiap unit lahan terkatagori landai hingga datar sehingga proses pelaksanaan mengatasi pembatas yang ada tidak terlalu besar.

Melihat hasil tahap pelaksanaan yang telah dilakukan untuk mengatasi faktor pembatas kesesuaian lahan pada tingkat sub kelas, petani kedelai perlu meningkatkan usahanya untuk memperoleh hasil yang lebih baik, tidak hanya pada aspek yang memiliki nilai pada katagori kurang baik saja melainkan kelima aspek yang menjadi faktor pembatas perlu di tingkatkan. Memperhatikan setiap unit lahan yang ada, pelaksanaan ketepatan masukan teknologi paling tinggi adalah unit lahan 16 dengan rata-rata mencapai tahap pelaksanaan 56,89\% yang termasuk dalam katagori sedang. Ketepatan masukan teknologi pada unit lahan 16 termasuk yang paling baik, namun pelaksanaannya masih perlu ditingkatkan karena masih dalam katagori sedang, sehingga dengan ditingkatkannya usaha yang dilakukan untuk mengatasi faktor pembatas dapat meningkatkan produktivitas lahan untuk tanaman kedelai.

Unit lahan terrendah adalah unit lahan 10 dengan rata-rata nilai mencapai tahap pelaksanaan 40,34\% yang termasuk kedalam katagori kurang baik. Kondisi ini juga dipengaruhi oleh keadaan geografis pada setiap unit lahan, yang mana dapat dilihat pula dari kelas kesesuaian yang berada pada kelas sesuai, hampir sesuai dan tidak sesuai serta proses pengolahan yang dilakukan setiap petani terhadap lahan yang dimilikinya. Tidak hanya itu, hasil penelitian ini menunjukkan bahwa secara kualitas lahan menurut Maitri (2011) termasuk dalam katagori rendah namun jika diberikan masukan dan pengelolaan yang benar dan 
sesuai maka lahan tersebut dapat meningkatkan kualitas lahannya yang berdampak pada peningkatan produktivitas lahan untuk tanaman kedelai.

\section{Produktivitas Lahan di Setiap Unit Lahan untuk Tanaman Kedelai di Kecamatan Dawan}

Produktivitas lahan untuk tanaman kedelai dapat dicari dengan mengetahui biaya masukan teknologi dan pendapatan petani kedelai pada masing-masing unit lahan di Kecamatan Dawan. Berikut ini adalah rata-rata biaya masukan teknologi, pendapatan dan prodktivitas lahan untuk tanaman kedelai seperti terlihat pada Tabel 3.

Tabel 3. Rata-Rata Biaya Masukan Teknologi, Pendapatan dan Produktivitas Lahan Untuk Tanaman Kedelai pada Masing-Masing Unit Lahan Di Kecamatan Dawan

\begin{tabular}{|c|c|c|c|c|c|c|c|c|c|c|c|c|}
\hline \multirow[b]{2}{*}{ No } & \multirow[b]{2}{*}{ SP } & \multirow[b]{2}{*}{$\begin{array}{c}\text { Respond } \\
\text { en }\end{array}$} & \multicolumn{4}{|c|}{ Rata-Rata Aspek Biaya-Biaya (Rp) } & \multirow[b]{2}{*}{$\begin{array}{l}\text { Rata-Rata } \\
\text { Pendapatan } \\
\text { Kotor (Rp) }\end{array}$} & \multirow{2}{*}{$\begin{array}{c}\text { Biaya } \\
\text { Masukan } \\
\text { Teknologi } \\
\text { (Rp) }\end{array}$} & \multirow{2}{*}{\begin{tabular}{|c|} 
Hasil \\
Pendapata \\
n Bersih \\
$(\mathbf{R p})$ \\
\end{tabular}} & \multirow[b]{2}{*}{$\begin{array}{l}\text { LLG } \\
\text { (Ha) }\end{array}$} & \multirow[b]{2}{*}{$\begin{array}{c}\text { Produktivita } \\
\text { s (Rp/Ha) }\end{array}$} & \multirow[b]{2}{*}{$\%$} \\
\hline & & & Bibit & $\begin{array}{c}\text { Tenaga } \\
\text { Kerja }\end{array}$ & $\begin{array}{c}\text { Pemasar } \\
\text { an }\end{array}$ & $\begin{array}{c}\text { Perawata } \\
\text { n }\end{array}$ & & & & & & \\
\hline [1] & {$[2]$} & {$[3]$} & [4] & [5] & [6] & [7] & [8] & [9] & [10] & {$[11]$} & [12] & [13] \\
\hline 1 & 1 & 2 & 126.000 & 75.000 & 0 & 180.000 & 1.750 .000 & 381.000 & 1.369 .000 & 0,325 & 4212307,692 & 16,87 \\
\hline 2 & 7 & 6 & $337.666,67$ & $376.666,67$ & 0 & $154.166,67$ & $3.483 .333,30$ & 868.500 & 2.614 .833 & 0,458 & 5705094,986 & 22,85 \\
\hline 3 & 10 & 5 & 147.200 & 228.000 & 0 & 130.000 & 1.186 .000 & 505.200 & 680.800 & 0,214 & 3181308,411 & 12,74 \\
\hline 4 & 13 & 9 & $249.444,44$ & $310.222,22$ & 0 & $342.222,22$ & $4.577 .777,80$ & $901.888,89$ & 3.675 .889 & 0,43 & 8548578,863 & 34,24 \\
\hline 5 & 16 & 8 & 206.875 & 153.000 & 0 & 143.750 & 1.300 .000 & 503.626 & 796.374 & 0,24 & 3318225 & 13,29 \\
\hline \multicolumn{2}{|c|}{ Jumlah } & 30 & 1.067 .186 & 1.142 .889 & 0 & 950.139 & 12.297 .111 & 3.160 .215 & 9.136 .896 & 2 & 24.965 .515 & 100 \\
\hline \multicolumn{3}{|c|}{ Rata-Rata } & 213437,2 & 228577,8 & $\mathbf{0}$ & 190027,8 & 2459422,2 & 632042,9778 & 1827379 & 0,333 & 4993102,99 & 20 \\
\hline
\end{tabular}

Sumber : Lampiran 04 dan Analisis Data Primer, 2020

$$
\begin{gathered}
\text { Keterangan : Kolom }(12)=\frac{\text { Kolom }(10)}{\text { Kolom }(11)} \\
\text { SP } \quad: \text { Satuan Pemetaan } \\
\text { LLG } \quad: \text { Luas Lahan Garapan }
\end{gathered}
$$

Tabel 3 menunjukkan bahwa rata-rata produksi kotor sebesar Rp. 2.459.422,2, dengan biaya ratarata yang dikeluarkan sebesar Rp. 632.042,98. Hasil perhitungan pendapatan kotor dikurang biaya yang dikeluarkan diperoleh rata-rata hasil bersih untuk areal didapatkan sebesar Rp. 1.827.379 dengan rata-rata produktivitas lahan untuk tanaman kedelai di Kecamatan Dawan mencapai Rp. 4.993.102,99/ha. rata-rata produksi kotor tertinggi berasal dari unit lahan 13 sebesar Rp. 4.577.777,80 dan rata-rata produksi kotor terendah berasal dari unit lahan 10 sebesar Rp. 1.186.000,00.

Memperhatikan biaya masukan yang dikeluarkan petani, rata-rata biaya paling tinggi diperoleh pada unit lahan 13 sebesar Rp.901.888,89, sedangkan rata-rata biaya terkecil didapat pada unit lahan 1 sebesar Rp. 381.000,00. Jika dilihat hasil bersih, maka diperoleh hasil bersih paling tinggi berada pada unit lahan 13 sebesar Rp. 3.675.889,00 dan untuk hasil bersih paling rendah terdapat pada unit lahan 10 sebesar Rp. 680.800,00. Rata-rata produktivitas lahan untuk tanaman kedelai mencapai Rp. 4.993.102,99/ha, dilihat pada tiap-tiap unit lahan, rata-rata produktivitas tertinggi diperoleh pada unit lahan 13 sebesar Rp. 8.548.578,86/ha atau 34,24\%. Untuk rata-rata produktivitas terendah terdapat pada unit lahan 10 sebesar Rp.3.181.308,41/ha atau 12,74\%. Selain itu, unit lahan 1 memiliki nilai rata-rata produktivitas sebesar Rp. 4.212.307,69/ha atau 16,87\%, untuk unit lahan 7 sebesar Rp. 5.705.094,99/ha atau 22,85\% dan untuk unit lahan 16 memiliki rata-rata produktivitas lahan sebesar Rp. 3.318.225/ha atau 13,29\%.

Menilai kecocokan/hubungan ketepatan masukan teknologi dengan produktivitas lahan untuk tanaman kedelai menggunakan bantuan tabel berupa membandingkan hasil analisis tabel. Hubungan ketepatan masukan teknologi terhadap faktor pembatas kesesuaian lahan pada tingkat sub kelas dengan produktivitas lahan untuk tanaman kedelai dapat diperhatikan pada Tabel 4. 
Tabel 4. Ketepatan Masukan Teknologi Terhadap Faktor Pembatas Kesesuaian Lahan pada Tingkat Sub Kelas dan Produktivitas Lahan untuk Tanaman Kedelai di Setiap Unit Lahan

\begin{tabular}{|c|c|c|c|c|c|}
\hline \multirow[t]{2}{*}{ No } & \multirow[t]{2}{*}{$\begin{array}{l}\text { Satuan } \\
\text { Pemetaan }\end{array}$} & \multicolumn{2}{|c|}{$\begin{array}{l}\text { Kesesuaian } \\
\text { Kualitatif }\end{array}$} & \multicolumn{2}{|c|}{ Kesesuaian Kuantitatif } \\
\hline & & Kelas & Sub Kelas & $\begin{array}{l}\text { Masukan } \\
\text { Teknologi }\end{array}$ & $\begin{array}{l}\text { Produktivitas } \\
\text { Lahan (Rp/Ha) }\end{array}$ \\
\hline (1) & (2) & (3) & (4) & (5) & (6) \\
\hline 1 & 1 & $\mathrm{~S}_{2}$ & $S_{2 \operatorname{trf}}$ & 48,30 & $4.212 .307,69$ \\
\hline 2 & 7 & $\mathrm{~N}_{1}$ & $\mathrm{~N}_{1 \mathrm{~s}}$ & 44,89 & $5.705 .094,99$ \\
\hline 3 & 10 & $\mathrm{~S}_{3}$ & $\mathrm{~S}_{3 \mathrm{rs}}$ & 40,34 & $3.181 .308,41$ \\
\hline 4 & 13 & $\mathrm{~S}_{3}$ & $\mathrm{~S}_{3 \mathrm{~ns}}$ & 51,46 & $8.548 .578,86$ \\
\hline 5 & 16 & $\mathrm{~S}_{3}$ & $\mathrm{~S}_{3 \mathrm{~s}}$ & 56,80 & $3.318 .225,00$ \\
\hline \multicolumn{2}{|c|}{ Jumlah } & & & 241,804255 & $24.965 .515,00$ \\
\hline $\mathrm{Ra}$ & a-Rata & & & 48,361 & $4.993 .102,99$ \\
\hline
\end{tabular}

Sumber : Analisis Data Primer,2020

Berdasarkan Tabel 4, dapat diketahui bahwa antara ketepatan masukan teknologi dan produktivitas lahan untuk tanaman kedelai memiliki hubungan atau saling berhubungan. Dilihat dari perbandingan tabel tersebut semakin besar nilai masukan yang diberikan berdampak pada produktivitas yang dihasilkan. Perbedaan produktivitas juga dipengaruhi oleh luas lahan yang ditanami kedelai. Setiap unit lahan yang ada memiliki nilai masukan yang bervariasi dari katagori tidak baik hingga sedang serta pendapatan produktivitas rata-rata keseluruhan unit lahan sebesar Rp. 4.993.102,99. Masukan pengelolaan yang baik akan berdampak baik pada produktivitas lahannya dan begitu sebaliknya, apabila masukan pengelolaan buruk maka produktivitasnya akan rendah. Mengetahui perbandingan tabel tersebut dapat diketahui hasil masukan dan produktivitas lahan di setiap unit lahannya. Pelaksanaan pengelolaan untuk dapat meningkatkan produktivitas sangat perlu ditingkatkan melihat pelaksanaan masukan teknologi masih dalam katagori sedang. Sementara itu, jika dibandingkan dengan kesesuaian lahan kualitatif dan kuantitatif yang ada, kualitas unit lahan yang rendah dapat diperbaiki dengan memberikan masukan pengelolaan yang benar sehingga akan meningkatkan produtkvitas lahannya. Selain itu, terdapat beberapa faktor yang mempengaruhi nilai produktivitas menjadi rendah yang mana termasuk kedalam kendala-kendala yang dihadapi petani kedelai.

Berdasarkan rekapitulasi yang telah dikemukakan pada sub hasil penelitian, nampak ketepatan masukan teknologi menunjukkan nilai rata-rata mencapai tahap pelaksanaan sebesar 48,36\% yang termasuk dalam katagori sedang. Jika diperhatikan pada setiap aspek akan terlihat aspek yang paling tinggi tahap pelaksanaannya adalah aspek media perakaran mencapai tahap pelaksanaan $66,24 \%$ yang termasuk dalam katagori baik. Sementara itu, aspek yang paling rendah tahap pelaksanaan adalah aspek medan sebesar 31,98\% termasuk kedalam katagori kurang baik. Hal ini dikarenakan kondisi wilayah pada unitunit lahan yang menjadi populasi di daerah penelitian memiliki kualitas medan yang tidak terjal.

Kondisi ini didukung oleh penelitian yang telah dilakukan oleh Maitri (2011) tentang pengaruh kesesuaian lahan terhadap produktivitas lahan kering untuk tanaman kedelai di Kecamatan Dawan yang didalamnya dijelaskan tekait kualitas lahan berupa medan yang kemiringan lerengnya bervariasi dari datar hingga terjal. Unit lahan 1,7 dan 10 memiliki kemiringan lereng datar, lereng melandai terdapat pada unit lahan 13, dan kemiringan melereng terdapat di unit lahan 16. Karakteristik batuan permukaan di 5 unit lahan yang dijadikan populasi di Kecamatan Dawan terdiri dari tanpa bebatuan hingga banyak bebatuan, unit lahan 1 termasuk dalam katagori tidak ada bebatuan, sedikit berbatu pada unit lahan 10,13,16, dan sedang berbatu pada unit 7. Memperhatikan kondisi tersebut, sejalan dengan usaha yang dilakukan oleh petani kedelai, dikarenakan kondisi medan yang tidak sulit menyebabkan usaha untuk mengatasi, hampir tidak ada yang berdampak pada rendahnya nilai yang diperoleh.

Bila diperhatikan sebaran pada masing-masing unit lahan, akan terlihat pelaksanaan tertinggi terdapat pada unit lahan 16 yang mencapai 56,81\% yang termasuk dalam katagori sedang. Unit lahan ini terletak pada bentuk lahan dataran fluvial kaki volkanis datar sampai berbukit agak bergelombang. Sementara itu, pelaksanaan terendah terdapat pada unit lahan 10 yang mencapai tahap pelaksanaan 40,34\% termasuk dalam katagori kurang baik. Kondisi ini menunjukkan bahwa ketepatan masukan teknologi masih perlu ditingkatkan lebih maksimal untuk mencapai produktivitas lahan untuk tanaman kedelai lebih tinggi, baik dilihat dari aspek maupun sebarannya. Produktivitas tanaman kedelai di Kecamatan Dawan sejauh ini masih tergolong tinggi dibandingkan dengan rata-rata produksi kedelai di setiap kecamatan yang ada di Kabupaten Klungkung. Walaupun memiliki produktivitas yang tinggi diantara kecamatan lainnya, ketepatan masukan teknologi masih perlu ditingkatkan lagi, karena katagori terbaik 
pelaksanaannya tergolong sedang dan katagori terbaik termasuk kurang baik, yang berdampak pada peningkatan produktivitas tanaman kedelai di Kecamatan Dawan. Rata-rata produktivitas lahan tanaman kedelai sebesar Rp. 4.993.102,99/ha. Melihat setiap unit lahan, nampak unit lahan 13 menunjukkan produktivitas lahan tertinggi mencapai Rp. 8.548.579,86/ha atau 34,24\%, sedangkan unit lahan 10 menunjukkan produktivitas lahan terendah mancapai Rp. 3.181.308,41/ha atau 12,74\%. Tinggi rendahnya produktivitas yang ada pada unit lahan tergantung pula pada luas lahan yang ditanami kedelai, selain dipengaruhi oleh faktor-faktor masukan teknologi dan faktor lainnya.

Berdasarkan analisis tabel yang dilakukan untuk mencocokan antara ketepatan masukan teknologi dengan produktivitas lahan untuk tanaman kedelai dengan cara membandingkan nilai keduanya, maka diperoleh hasil bahwa ketepatan masukan teknologi dan produktivitas lahan memiliki hubungan atau kecocokan satu sama lain. Kedua aspek tersebut tidak dapat dipisahkan karena berdampak satu sama lain. Semakin baik pengelolaan yang diberikan maka akan berdampak pada peningkatan produktivitas lahannya dan begitu sebaliknya semakin buruk pengelolaannya maka semakin kecil produktivitasnya. Terlepas dari kendala yang dihadapi petani juga menjadi faktor tinggi rendahnya produktivitas yang diperoleh, terutama permasalahan yang dialami pada masa panen.

\section{Kendala-Kendala yang di Hadapi Petani Kedelai Dalam Menentukan Masukan Teknologi dan Produktivitas Lahan}

Produktivitas kedelai disetiap unit lahannya di Kecamatan Dawan masih terdapat banyak permasalahan yang dihadapi petani kedelai dalam membudidayakan tanaman kedelai.

Tabel 5. Indentifikasi Kendala-Kendala yang di Hadapi Petani Kedelai di Setiap Unit Lahan di Kecamatan Dawan

\begin{tabular}{|c|c|c|c|c|c|c|}
\hline \multirow[t]{2}{*}{ No } & \multirow[t]{2}{*}{ SP } & \multirow[t]{2}{*}{$\mathbf{R}$} & \multicolumn{3}{|c|}{ Kendala-Kendala Petani Kedelai } & \multirow{2}{*}{$\begin{array}{c}\text { Keterlibatan } \\
\text { Instansi } \\
\text { Pemerintah } \\
\end{array}$} \\
\hline & & & Masa Pembibitan & $\begin{array}{c}\text { Masa } \\
\text { Tanam/Perawatan }\end{array}$ & Masa Panen & \\
\hline (1) & (2) & (3) & (4) & (5) & (6) & (7) \\
\hline 1 & 1 & 2 & $\begin{array}{ll}- & \text { Kesulitan Air } \\
- & \text { Kesulitan } \\
\text { mencari bibit } \\
\text { unggul }\end{array}$ & $\begin{array}{ll}- & \text { Kesulitan air } \\
\text { - } & \text { Hama (Tikus, } \\
\text { Balang Sangit, } \\
\text { Wereng) } \\
\text { - } \begin{array}{l}\text { Cuaca buruk } \\
\text { (polong tidak isi } \\
\text { buah) }\end{array} \\
\end{array}$ & $\begin{array}{ll}- & \text { Cuaca buruk } \\
\text { (Hujan) }\end{array}$ & \begin{tabular}{|ll}
- & Sosialisasi dari \\
& Dinas Pertanian \\
- & Bantuan Bibit \\
- & Bantuan Subsidi \\
& Pupuk dan Obat
\end{tabular} \\
\hline 2 & 7 & 6 & $\begin{array}{ll}\text { - } & \text { Bibit kurang } \\
& \text { bagus } \\
\text { - } & \text { Hama (Tikus) }\end{array}$ & $\begin{array}{ll}\text { - } & \text { Serangan Hama } \\
\text { (Ulat, Tikus, } & \\
\text { Balang, dan } \\
\text { Wereng) } \\
\text { - } & \text { Cuaca Buruk } \\
\end{array}$ & $\begin{array}{ll}\text { - } & \text { Cuaca Buruk } \\
\text { (Hujan) } \\
\text { - } \quad \text { Pemasaran } \\
\text { (Harga } \\
\text { Anjlok) } \\
\end{array}$ & \begin{tabular}{|ll}
- & Sosialisasi dari \\
& Dinas Pertanian \\
- & Subsidi \\
& Bibit,Pupuk dan \\
Obat
\end{tabular} \\
\hline 3 & 10 & 5 & $\begin{array}{ll}\text { - } & \text { Hama } \\
\text { - } & \text { Bibit kecil- } \\
& \text { kecil } \\
\text { - } & \text { Kesulitan } \\
& \text { mencari bibit } \\
& \text { unggul } \\
\text { - } & \text { Kekurangan } \\
& \text { air pada } \\
\text { musim } \\
\text { kemarau } \\
\end{array}$ & $\begin{array}{l}\text { - Hama (Wereng, } \\
\text { Walang Sangit, } \\
\text { Tikus) } \\
\text { - Gulma } \\
\text { - } \text { Bibit cepat } \\
\text { mengalami } \\
\text { pembusukan }\end{array}$ & $\begin{array}{ll}\text { - } & \text { Cuaca Buruk } \\
\text { (Hujan) } \\
\text { - } \quad \text { Kesulitan } \\
\text { Mencari } \\
\text { Tenaga } \\
\text { Merontokkan } \\
\text { Kedelai } \\
\text { - Pemasaran } \\
\text { (Harga } \\
\text { Anjlok) } \\
\end{array}$ & $\begin{array}{ll}\text { - } & \text { Sosialisasi dari } \\
& \text { Dinas Pertanian } \\
\text { - } & \text { Subsidi } \\
& \text { Bibit,Pupuk dan } \\
\text { Obat }\end{array}$ \\
\hline 4 & 13 & 9 & $\begin{array}{ll}- & \text { Cuaca buruk } \\
\text { - } & \text { Hama } \\
\text { - } & \text { Kesulitan } \\
& \text { mencari bibit }\end{array}$ & $\begin{array}{ll}- & \text { Ternak } \\
\text { merusak } \\
\text { tanaman } \\
\text { - } & \text { Hama (tikus) }\end{array}$ & $\begin{array}{ll}\text { - } & \text { Kesulitan } \\
\text { mencari } \\
\text { tenaga untuk } \\
\text { merontokkan } \\
\text { kedelai } \\
\text { - } \quad \text { Cuaca buruk } \\
\text { - } & \text { Harga pasar } \\
\text { tidak } \\
\end{array}$ & $\begin{array}{ll}- & \text { Sosialisasi dari } \\
\text { Dinas Pertanian } \\
\text { - } & \begin{array}{l}\text { Subsidi Pupuk, } \\
\text { bibit }\end{array}\end{array}$ \\
\hline
\end{tabular}




\begin{tabular}{|c|c|c|c|c|c|c|}
\hline & & & & & $\begin{array}{l}\text { sebanding } \\
\text { dengan harga } \\
\text { bibit }\end{array}$ & \\
\hline 5 & 16 & 8 & $\begin{array}{ll}-\quad & \text { Kekurangan air } \\
\text { - } & \text { Kesulitan } \\
\text { mencari bibit } \\
\text { unggul }\end{array}$ & $\begin{array}{ll}\text { - } & \text { Hama (Walang } \\
& \text { Sangit, Ulat) } \\
\text { - } & \text { Cuaca buruk } \\
\text { (polong tidak } & \text { berisi buah) } \\
\text { - } & \text { Pupuk mahal } \\
\text { - } & \text { Kesulitan air }\end{array}$ & $\begin{array}{ll}- & \text { Cuaca Buruk } \\
- & \text { Pemasaran } \\
& \text { (Harga } \\
& \text { Anjlok) }\end{array}$ & \begin{tabular}{|ll} 
- & Sosialisasi dari \\
& Dinas Pertanian \\
- & Subsidi Pupuk \\
& dan Bibit
\end{tabular} \\
\hline
\end{tabular}

Sumber : Analisis Data Primer, 2020

Berdasarkan Tabel 5 dapat diketahui bahwa masih terdapat kendala yang dihadapi petani disetiap unit lahan dan rata-rata permasalahan petani yang dihadapi dibagi menjadi 3 fase, yakni fase pembibitan, fase tanam/perawatan dan fase panen. Permasalahan petani di setiap unit lahan memiliki kemiripan satu dengan unit lahan lainnya yang ada di Kecamatan Dawan. Kendala-kendala tersebut ditemui hampir disetiap unit lahan yang ditanami kedelai yang perbedaannya hanya terletak pada kendala kekurangan air yang dialami beberapa unit lahan seperti penjelasan pada tabel sebelumnya. Berdasarkan identifikasi kendala petani kedelai yang telah dilakukan, dapat di jabarkan permasalahan yang paling mendominasi petani kedelai di Kecamatan Dawan. Kendala-kendala petani kedelai di Kecamatan Dawan dapat diperhatikan pada Tabel 6.

Tabel 6. Kendala-Kendala yang di Hadapi Petani Kedelai di Kecamatan Dawan

\begin{tabular}{|c|c|c|c|}
\hline No & Fase/Masa & Kendala-Kendala Petani & Usaha Petani \\
\hline & Pembibitan & $\begin{array}{l}\text { 1. Kekurangan } \\
\text { Bibit Unggul/Kesulitan } \\
\text { mencari bibit unggul, } \\
\text { 2. Hama } \\
\text { 3. Kesulitan } \\
\text { air/kekurangan air, } \\
\text { 4. Cuaca Buruk, }\end{array}$ & $\begin{array}{l}\text { 1. Mencari ke subak yang telah panen palawija, } \\
\text { tengkulak(pengepul),dan pasar. } \\
\text { 2. Pembuatan jebakan tikus. } \\
\text { 3. Kordinasi dengan subak di hulu terkait } \\
\text { pengelolaan air dari sumber irigasi di } \\
\text { Kecamatan Dawan. } \\
\text { 4. Pengecekan bibit dan proses pembibitan } \\
\text { ulang berdasarkan kondisi bibit } \\
\text { sebelumnya. }\end{array}$ \\
\hline & $\begin{array}{l}\text { Tanam/Pera } \\
\text { watan }\end{array}$ & $\begin{array}{l}\text { 1. Serangan Hama } \\
\text { (Tikus, Walang } \\
\text { Sangit, Wereng, } \\
\text { Ulat) dan gulma, } \\
\text { 2. Cuaca buruk, } \\
\text { 3. Kesulitan air } \\
\text { 4. Pupuk mahal }\end{array}$ & $\begin{array}{l}\text { 1. Menggunakan obat berupa pestisida (alami } \\
\text { maupun kimia)serta pembersihan areal lahan. } \\
\text { 2. Kordinasi dengan subak di hulu terkait } \\
\text { pengelolaan air dari sumber irigasi di } \\
\text { Kecamatan Dawan dan menunggu air mengalir } \\
\text { ke petak-petak lahan. } \\
\text { 3. Menggunakan bahan organik (pupuk kandang). }\end{array}$ \\
\hline & Panen & $\begin{array}{l}\text { 1. Cuaca Buruk } \\
\text { menyebabkan gagal } \\
\text { panen atau hasil } \\
\text { produksi menurun, } \\
\text { 2. Harga kedelai } \\
\text { anjlok } \\
\text { (pemasaran yang } \\
\text { ditentukan oleh } \\
\text { tengkulak). }\end{array}$ & $\begin{array}{l}\text { 1. Pohon kedelai dikumpulkan jadi satu lalu } \\
\text { ditutup menggunakan terpal agar tidak basah, } \\
\text { jika terlanjur mengalami pembusukan, pohon } \\
\text { dan buah dijadikan pupuk. } \\
\text { 2. Menerima harga tengkulak atau menjual } \\
\text { kepasar langsung. }\end{array}$ \\
\hline
\end{tabular}

Sumber : Analisis Data Primer, 2020

Berdasarkan Tabel 6, nampak kendala-kendala yang dihadapi petani kedelai di Kecamatan Dawan dan usaha yang selama ini dilakukan untuk mengurangi atau mengatasi masalah tersebut agar terus dapat membudidayakan tanaman kedelai. Pada fase pembibitan kesulitan mencari bibit unggul merupakan masalah utama yang dihadapi petani di setiap unit lahan yang ada. Selain permasalahan bibit unggul, hama dan kesulitan air menjadi kendala selanjutnya yang dialami hampir semua petani kedelai di Kecamatan Dawan pada masa pembibitan. Permasalahan terkait hama dan kesulitan air tidak hanya dirasakan atau dialami pada masa pembibitan saja, melainkan dialami pula pada masa tanam/atau perawatan tanaman 
yang menyebabkan tanaman kedelai ada yang mengalami kerusakan ataupun pertumbuhannya tidak baik seperti daun yang rusak akibat hama dan buah yang rusak. Permasalahan ini tidak hanya dialami satu unit lahan saja melainkan seluruh unit lahan yang ditanami kedelai mengalami kendala tersebut.

Sementara itu, permasalahan yang dialami pada masa panen yaitu harga pasaran kedelai yang mengalami fluktuatif cenderung menurun dan kondisi cuaca buruk pada saat panen menyebabkan produksi yang diperoleh atau bahkan mengalami gagal panen. Harga panen kedelai selama ini masih tergantung dari tengkulak, sehingga harga jual hasil panen cenderung murah dan jauh berbeda dari harga bibit yang dibeli pada tengkulak pada masa pembibitan. Harga hasil panen biasanya dibeli dengan satuan rondong yang diakumulasi kedalam kg menjadi 2 kg dalam 1 rontong. 1 rontong dihargai paling tinggi sebesar Rp. 15.000 bahkan pernah menyentuh harga Rp. 10.000/rontong.

Pemasaran kedelai masih menjadi permasalahan penting dalam pengembangan kedelai kedepannya. Hal ini terungkap dari hasil wawancara dengan petani kedelai yang menjadi sampel pada penelitian ini. Petani menginginkan adanya kepastian harga jual hasil panen kedelai dan pemerintah tidak hanya mendampingi petani sebatas pada perawatan saja melainkan mendampingi hingga proses pemasaran hasil. Jika ada penentuan harga atau jaminan harga maka petani akan lebih bersemangat untuk menanam kedelai. ketidak stabilan harga yang ada sampai saat ini menjadi faktor utama beralihnya petani kedelai ke budidaya tanaman palawija lainnya yang hasilnya lebih menjanjikan.

Berdasarkan analisis yang telah dilakukan pada sub hasil penelitian, maka diperoleh kendala-kendala yang dialami petani kedelai di Kecamatan Dawan. Kendala-kendala yang dihadapi dibagi menjadi tiga masa yakni masa pembibitan, masa tanam/perawatan dan masa panen. Setiap masa atau fase ini memiliki kendalanya tersendiri yang mana variasi kendala yang dihadapi petani kedelai bersifat homogen yang artinya kendala kendala tersebut dialami di setiap unit lahan yang ditanami kedelai. Pada fase pembibitan kendala yang besar dialami petani adalah kesulitan mencari bibit unggul. Bibit yang selama ini digunakan diperoleh dari hasil tukar dengan subak yang telah panen palawija atau membeli dari tengkulak kedelai. Bantuan yang pernah diberikan oleh pemerintah berupa bibit belum berjalan efektif seperti apa yang diharapkan.

Hal inilah yang menjadi kendala utama yang dihadapi petani kedelai di Kecamatan Dawan. Selain itu, hama, kesulitan air, dan cuaca menjadi faktor selanjutnya sebagai masalah yang dihadapi petani kedelai di Kecamatan Dawan pada masa pembibitan. Pemberantasan hama sejauh yang dilakukan petani cukup efektif dengan memberikan obat ataupun racun. Kesulitan air yang dialami terkadang membuat petani tidak mendapat air sehingga tidak dapat menanam tanaman palawija. Pembagian air di setiap subaknya perlu lebih ditingkatkan koordinasinya sehingga subak yang dihilir tetap dapat memperoleh air untuk proses budidaya tanaman palawija terutama kedelai.

Kendala yang dihadapi petani pada masa tanam/perawatan yang paling dominan adalah serangan dari hama baik berupa ulat, walang sangit, wereng, dan tikus yang menyerang tanaman kedelai baik batang, buah maupun daun yang berdampak pada kerusakan tanaman kedelai. Seperti pada masa pembibitan, usaha petani mengatasi serangan hama dengan melakukan penyemprotan pestisida kimia maupun organik. Cuaca buruk seperti hujan lebat disertai kilat dan gemuruh juga berdampak pada tanaman kedelai terutama buah kedelai yang tidak berisi bijinya yang mengakibatkan pada masa panen mengalami gagal panen.

Selain gagal panen yang akan dihadapi petani pada masa panen, harga kedelai yang anjlok juga dialami petani pada masa panen. Harga jual kedelai lebih rendah dibandingkan dengan harga beli bibit kedelai. Harga jual hasil panen kedelai sangat ditentukan oleh harga yang diberikan tengkulak. Tengkulak mengatur sendiri harga beli hasil panen kedelai petani, yang menyebabkan harga beli dari tengkulak rendah. Kondisi inilah yang menyebabkan harga jual kedelai disetiap unit lahan terkadang berbeda. Harga paling tinggi yang ditawarkan tengkulak kepada petani saat hasil panen bagus hanya Rp.15.000/rontong. Apabila panen raya maka harga kedelai akan jatuh yang paling rendah dapat berkisar Rp.10.000/rontong. Harga yang anjlok tersebut, menyebabkan petani sering mengalami kerugian, karena penghasilan yang diperoleh tidak sebanding dengan biaya yang dikeluarkan atau keuntungan yang diperoleh kecil.

Pemasaran kedelai masih menjadi permasalahan penting dalam pengembangan kedelai kedepannya. Hal ini terungkap dari hasil wawancara dengan petani kedelai yang menjadi sampel pada penelitian ini. Petani menginginkan adanya kepastian harga jual hasil panen kedelai dan pemerintah tidak hanya mendampingi petani sebatas pada perawatan saja melainkan mendampingi hingga pemasaran hasil panen agar petani tidak mengalami kerugian. Ketidakstabilan harga yang ada sampai saat ini menjadi faktor utama beralihnya petani kedelai ke budidaya tanaman palawija lainnya yang hasilnya lebih menjanjikan. Hal ini didukung oleh Tahlim et al, 2003 (dalam Surachman, 2012), terkait pengembangan produksi kedelai dalam negeri masih mengahadapi beberapa permasalahan, antara lain: 1) Usaha perluasaan areal pada lahan bukaan baru pada umumnya menghadapi kendala kemasaman tanah yang tinggi, 2) Lahan bukaan baru berkontur bergelombang/berbukit sehingga rentan terhadap erosi, 3) Terbatasnya keterbatasan benih 
unggul bermutu baik dari segi jumlah maupun kualitas saat diperlukan, 4) Terbatasnya ketersediaan teknologi yang bersifat spesifik lokasi, 5) Rendahnya adopsi teknologi di tingkat petani, 6) Rendahnya tingkat harga yang diterima petani yang di refleksikan makin menurunnya nilai tukar petani.

Berdasarkan hasil proyeksi penawaran dan permintaan komoditas pertanian yang dilaksanakan Pusat Penelitian Sosial Ekonomi Petani (2000), dalam Surachman (2012), yang mengemukakan bahwa rendahnya produktivitas aktual yang dicapai diduga disebabkan oleh: 1) Tidak adanya kepastian harga komoditas pangan terutama kedelai di tingkat petani, 2) Penghapusan subsidi sarana produksi yang menyebabkan meningkatnya biaya produksi, sehngga petani tidak mampu menerapkan teknologi usahatani secara baik dan benar. Hasil proyeksi tersebut sejalan dengan apa yang diterjadi di daerah penelitian, subsidi pupuk yang mulai dikurangi oleh pemerintah menjadikan meningkatnya biaya produksi yang dikeluarkan oleh petani kedelai dan belum adanya kepastian harga komoditas kedelai di tingkat petani juga menjadi masalah rendahnya produktivitas lahan untuk tanaman kedelai. Kondisi semacam ini, membuat petani mulai beralih untuk tidak menanam kedelai. Petani lebih memilih untuk membudidayakan tanaman palawija lainnya yang hasil dan harganya lebih stabil. Penyebab tersebut juga mengakibatkan luas lahan yang ditanami kedelai juga berkurang. Adanya upaya untuk meningkatkan produksi kedelai harus disertai dengan perencanaan yang sesuai dengan setiap kondisi wilayah, pelaksanaan yang yang tepat guna dan evaluasi yang berkelanjutan, sehingga keselarasan terutama dalam penyelenggaraannya (kebijakan, penggerakan, pembinaan, pelayanan dan pengendalian) dapat terwujud.

\section{Simpulan dan saran}

Ketepatan masukan teknologi mengatasi faktor pembatas kesesuaian lahan pada tingkat sub kelas untuk tanaman kedelai di masing-masing unit lahan yang menjadi populasi unit lahan di daerah penelitian menunjukkan nilai rata-rata tahap pelaksanaan 48,36\% yang termasuk dalam katagori sedang. Unit lahan 16 menunjukkan nilai rata-rata tertinggi dengan nilai tahap pelaksanaan $56,81 \%$ termasuk dalam katagori sedang, sedangkan rata-rata terendah terdapat pada unit lahan 10 dengan rata-rata nilai tahap pelaksanaan 40,34\% termasuk dalam katagori kurang baik. Sejauh ini rata-rata produktivitas tanaman kedelai di Kecamatan Dawan sebesar Rp.4.993.102,99/ha. Rata-rata produktivitas tertinggi di setiap unit lahan terdapat pada unit lahan 13 sebesar Rp. 8.548.578,86/ha dan rata-rata produktivitas terendah terdapat pada unit lahan 10 sebesar 3.181.308,41/ha. Ketepatan masukan teknologi terhadap faktor pembatas kesesuaian lahan pada tingkat sub kelas dengan produktivitas memiliki kecocokan atau saling berhubungan satu sama lain. Kendala-kendala yang dihadapi petani kedelai di Kecamatan Dawan di bagi menjadi 3 masa. Kendala yang paling dominan dialami oleh setiap unit lahan untuk tanaman kedelai pada fase pembibitan adalah kesulitan mencari bibit kedelai yang unggul. Kendala yang dihadapi pada masa tanam atau perawatan yang paling dominan adalah serangan hama dan kondisi cuaca yang dapat menyebabkan gagal panen. Permasalahan utama yang dihadapi pada masa panen adalah harga jual kedelai petani yang anjlok turun dan kondisi cuaca yang menyebabkan berkurangnya hasil panen. Adapun saran yang diberikan sebagai berikut, 1) kepada petani kedelai supaya dapat meningkatkan pengelolaan pada lahan pertaniannya untuk tanaman kedelai, 2) bagi kalangan akademisi dapat melakukan penelitian serupa terkait kesesuaian lahan untuk tanaman kedelai atau tanaman palawija lainnya, 3) bagi Pemerintah Kabupaten Klungkung dapat dijadikan sebagai pertimbangan untuk memberikan bantuan kepada petani sesuai dengan kebutuhan yang dibutuhkan.

\section{Daftar Rujukan}

Adnyana, Ade Putra. 2012. Kesesuaian Lahan Kuantitatif Untuk Tanaman Mangga di Kecamatan Tejakula, Kabupaten Buleleng (Tinjauan Geografi Pertanian). Skripsi. Universitas Pendidikan Ganesha Singaraja.

Atmoko Sektiawan, Dwi. 2005. Arahan Pengembangan Komoditas Pertanian Berdasarkan Analisis Kesesuaian Lahan di Kabupaten Pasuruan. Tesis (diterbitkan). Program Studi Pascasarjana dan Pengembangan Wilayah, ITB. https://hub.satudata.bappenas.go.id/dataset/arahanpengembangan-komoditas-pertanian-berdasarkan-analisis-kesesuaian-lahan-di-kabupatenpasuruan

Djaenudin, D., Marwan, H., Subagja, H., dan A. Hidayat. 2011. Petunjuk Teknis Evaluasi Lahan Untuk Komuditas Pertanian. Balai Besar Litbang Sumberdaya Lahan Petanian, Badan Litbang Pertanian, Bogor. 36p. http://bbsdlp.litbang.pertanian.go.id/ind/index.php/publikasi-3/petunjuk-teknisevaluasi-lahan-untuk-komoditas-pertanian

Dwi Sulistiyono, Abidin. 2010. Evaluasi Kesesuaian Lahan dan Produktivitas Tanaman Jagung di DAS Grindulu Hulu Kabupaten Pacitan dan Ponorogo Tahun 2009. Skripsi (diterbitkan). Fakultas 
Keguruan dan Ilmu Pendidikan, Universitas Sebelas Maret Surakarta. https://eprints.uns.ac.id/10873/1/Unlock-a (10).pdf

FA0.1976. A Frame Work Land Evaluation. Roma : Soil Bulletin.

Maitri, Nyoman Alita Udaya. 2011. Pengaruh Kesesuaian Lahan terhadap Produktivitas Lahan Kering untuk Tanaman Kedelai di Kecamatan Dawan, Kabupaten Klungkung. Skripsi. Universitas Pendidikan Ganesha Singaraja.

Mega, I Made. I Nyoman Dibia, I G P Ratna Adi, Tati Budi Kusmiyarti. 2010. Buku Ajar Klasifikasi Tanah dan Kesesuaian Lahan. Denpasar : Program Studi Agroteknologi Fakultas Pertanian Universitas Udayana. https://docplayer.info/121091-Klasifikasi-tanah-dan-kesesuaian-lahan.html

Mohammad Faizin, Nurhuda. 2017. Evaluasi Kesesuaian Lahan Tanaman Padi, Jagung, dan Jeruk Pada Tanah Sawah di Kecamatan Kencong, Jombang dan Umbulsari Kabupaten Jember. Skripsi. Fakultas Pertanian, Universitas Jember. http://repository.unej.ac.id/handle/123456789/82043

Ritung, S., K. Nugroho, A. Mulyani, dan E. Suryani. 2011. Petunjuk Teknis Evaluasi Lahan Untuk Komoditas Pertanian (Edisi Revisi). Balai Besar Penelitian dan Pengembangan Sumberdaya Lahan Pertanian, Balai Penelitian dan Pengembangan Pertanian, Bogor. 168 hal.

Surachman, Arif. Hendriadi A, Budi Kartiwa, Apri Sulistyo, dan Retno Sri H M. 2012. Pencapaian Swasembada Kedelai Pada Tahun 2014 dengan Pendekatan Dinamika Sistem (System Dynamics). Jakarta : Badan Penelitian dan Pengembangan Pertanian. http://www.litbang.pertanian.go.id/buku/aplikasisystem-modelling/

Sriartha, I Putu. 2000. Geografi Pertanian. Singaraja: Sekolah Tinggi Keguruan dan Ilmu Pendidikan.

Yunus, Hadi Sabari. 2010. Metode Penelitian Wilayah Kontemporer. Yogyakarta:Pustaka Pelajar. 